\title{
Effectiveness of Mindfulness on Decreasing Stress in Health Professional Students: A Systematic Review
}

\author{
Akhmad Yanuar ${ }^{1}$, Meidiana Dwidiyanti ${ }^{2}$, Diyan Yuli $W^{3}$ \\ ${ }^{1}$ Student of Master Program in Nursing, Diponegoro University, Semarang, Indonesia \\ ${ }^{2.3}$ Department of Nursing, Faculty of Medicine, Diponegoro University, Semarang, \\ Indonesia \\ Corresponding Author: Meidiana Dwidiyanti (mdwidiyanti@gmail.com)
}

\begin{abstract}
Background: Stress in health professional students is increasing every year. Therefore it is necessary to implement stress management for the students. Mindfulness is an alternative which can be used to deal with stress.

Purpose: The purpose of this systematic review is to describe the effectiveness of mindfulness on decreasing stress in health professional students.

Methods: This systematic review was conducted by searching relevant articles published in online databases EBSCO, Science Direct, PubMed, and Google. The search was restricted to the full-text articles published in 2010-2017 and employed the RCTs and non-RCTs research designs with a mindfulness intervention.

Results: Of the ten articles reviewed, it was found that mindfulness could decrease stress in professional health students with a very significant $p$-value. The types of mindfulness administered to the health professional students included yoga therapy, MBSR therapy, and meditation therapy. In average, MBSR therapy is used for health professional students. This intervention is practiced through meditation which lasts for 5-35 minutes for 3-6 weeks.

Conclusion: The study reported that, in average, the intervention to decrease stress in health professional students is performed by using MBSR with a meditation of 5-35 minutes. The intervention is done for 3-6 weeks. Results found that MBSR mindfulness could decrease stress. Further research is needed to explore the effectiveness of mindfulness on other subjects such as students who get scholarships.
\end{abstract}

Keywords: Health professional students, health, mindfulness, stress, systematic review

\section{BACKGROUND}

High levels of stress are mostly found in medical students and other groups of students of healthcare professionals. A study on the prevalence of stress on medical students had been conducted in Malaysia with 396 participants. The results found that almost $41.9 \%$ of students experienced stress.

More than $29 \%$ of students reported experiencing stress in Korea and the United States (American College Health Association-National College of Health Assessment [ACHANCHA], 2013; Chung and Kim, 2010). Stress is known to cause social problems or suicide. Indeed, suicide is a serious problem in Korea and is the leading cause of death 
in Korea in the age of twenties (Statistics of Korea, 2012). The American College Health Association (ACHA) has implemented the need of mental health care for the students in the nation and promoted health programs (Buchanan, 2012).

Stress is an important psycho-social factor in the educational process that can affect the academic achievement and welfare of the students (Jimenez et al., 2010). Many students were reported to significantly experienced stress since they had to work with patients in a clinical setting. The most stressful aspect of the nursing students' clinical practice was that the students directly see and witness the pain and suffering of the patients (Jimenez et al., 2010). However, for nursing students, the level of academic stress is even higher than clinical stress (Chan et al., 2011).

MBSR programs have been studied and received much attention. Scientific evidence has shown MBSR could reduce the stress of an individual through mind-body connections; practice in self-awareness in fixing his problems, by not rejecting the events that happen to him, and not thinking too deeply about the event that will happen tomorrow (Center for Mindfulness 2014; Kabat-Zinn, 2003). MBSR is an open opment in the setting of behavioral medicine for populations with various chronic pain and stress-related disorders (Baer, 2009). As Baer pointed out, the standard of MBSR is conducted as a 3 to the 6-week course for 5-35 minutes per week plus home exercises. An intensive mindfulness session throughout the day for 7-8 hours is performed in the sixth week. Some skills of mindfulness meditation are also taught. Body detection is a 45-minute practice where the attention is directed to the wrong areas of the body while lying down. Sitting meditation is practiced by sitting in a relaxed and awake position with closed eyes and attention to the sensation of breathing. Hath yoga is taught to help someone achieve a sensation of awareness/mindfulness of the body during movement and stretching. Participants also train their attention to walk, stand and eat.

\section{PURPOSE}

The purpose of this systematic review is to describe the effectiveness of mindfulness on decreasing stress in health professional students.

\section{METHODS}

\section{Study design}

This study is a systematic review. Relevant articles were searched with some inclusion and exclusion criteria and keywords. A further review was then conducted to determine the articles used in this study.

\section{Inclusion and exclusion criteria}

The inclusion criteria of this study are the articles which used the students of health professionals such as medicine, psychology, nursing, and community health who were practicing mindfulness. Meanwhile, the exclusion criteria are articles that do not have the full text of pdf format, provision of intervention other than mindfulness, and respondents out of the inclusion criteria.

\section{Literature search strategies}


The articles were searched through the online database of EBSCO, Science Direct, PubMed, and Google Scholar. An advance search was performed using the keywords of mindfulness, stress reduction, and health professional students. The results identified 1450 articles from EBSCO, 1000 articles from Science Direct, 1100 articles from PubMed, and 116 articles from Google Scholar.

A further review was conducted by screening the articles which had full text in pdf format and were published in 2009 to 2017. The results identified 44 articles from EBSCO, 40 articles from Science Direct, 46 articles from PubMed and 38 from Google Scholar.

All article titles which are deemed appropriate to the purpose of the study were screened to know whether the title of the article was similar and whether there were significant effects of mindfulness therapy. Ten best articles were selected. One out of these nine articles reported no significant effects of mindfulness since after a 6-month intervention of mindfulness, the related behavior reoccurred.

Table 1. Literature search strategy

\begin{tabular}{|l|c|c|c|c|}
\hline Searching tools & EBSCO & Science Direct & PubMed & Google Scholar \\
\hline Results of searching & 1450 & 1000 & 1100 & 160 \\
\hline Full text, pdf, 2010-2017 & 44 & 40 & 46 & 38 \\
\hline Similar titles & 1 & - & - & - \\
\hline $\begin{array}{l}\text { Eligible, suitable with the } \\
\text { inclusion and exclusion } \\
\text { criteria. }\end{array}$ & 3 & 4 & 2 & 1 \\
\hline
\end{tabular}

\section{Assessment of quality of the study}

The Critical Appraisal Skills Program (CASP) was used in this study to assess the quality of the articles. CASP was accessed from www.casp-uk.net. The critical appraisal was performed by the researchers to know the quality of the article.

\section{Data Extraction}

Data extraction was performed by exploring the articles based on five themes: author, participant, intervention, and outcomes.

\section{Data synthesis}

Data were narratively described. The presentation of data included article characteristics, the effectiveness of the intervention, and outcomes after the implementation of the therapy.

\section{RESULTS}

\section{Characteristics of the study}

Ten articles were identified to use RCT (Randomized Control Trial) and non RCT design with high quality. One article published in 2009 to 2017 mentioned that a 3-6 week mindfulness therapy could reduce depression in students 
HOLISTIK NURSING AND HEALTH SIENCE 1, (1), 2018 1-11

Table 2. Summary of the study

\begin{tabular}{|c|c|c|c|c|c|c|c|}
\hline Authors & Study design & Population & Control & Intervention & Outcomes Analyzed & $\begin{array}{l}\text { Time Frame } \\
\text { Measurement }\end{array}$ & Outcomes \\
\hline $\begin{array}{l}\text { Barbosa et al. } \\
\text { (1) }\end{array}$ & $\begin{array}{l}\text { Non-RCT } \\
\text { matched } \\
\text { control }\end{array}$ & $\begin{array}{l}\mathrm{N}=12 \text { (Pod, } \\
\mathrm{OT}, \mathrm{PT}, \\
\text { nursing, and } \\
\text { physician } \\
\text { assistant) }\end{array}$ & $\begin{array}{l}\mathrm{N}= \\
14(\text { Pod, } \\
\text { OT, PT, } \\
\text { Nursing, } \\
\text { and } \\
\text { Physician } \\
\text { Assistant). }\end{array}$ & $\begin{array}{l}\text { MBSR eight weeks / two and a } \\
\text { half hours + eight -hour retreat } \\
\text { Mindful awareness daily } \\
\text { activities and communication } \\
\text { Med home practice of } 35 \\
\text { minutes, formal MF, 5-15 } \\
\text { minutes of informal practice } \\
\text { Mindful movement qigong, } \\
\text { body scan, yoga, sitting med } \\
\text { mindful awareness of daily } \\
\text { routines/communication }\end{array}$ & BAI, JSPE, and MBI & $\begin{array}{l}\text { Baseline post at } \\
\text { week } 8 \\
\text { Follow-up week } \\
11\end{array}$ & $\begin{array}{l}\text { Anxiety in intervention } \\
\text { gp week } 8 \text { and } 11\end{array}$ \\
\hline $\begin{array}{l}\text { Song and } \\
\text { Lindquist } \\
\text { (2) }\end{array}$ & $\mathrm{RCT}$ & $\begin{array}{l}\mathrm{N}=23 \\
\text { nursing }\end{array}$ & $\begin{array}{l}\mathrm{N}=21 \\
\text { nursing } \\
\text { Wait listed } \\
\text { control }\end{array}$ & $\begin{array}{l}\text { MBSR 2hours / week for eight } \\
\text { weeks } \\
\text { Consisted of guided instruction } \\
\text { on MF med, gentle stretching } \\
\text { and group discussion, and } \\
\text { home assignments }\end{array}$ & $\begin{array}{l}\text { DASS-21 } \\
\text { MAAS - Korean } \\
\text { Version }\end{array}$ & Before - After & $\begin{array}{l}\text { Depression, anxiety, } \\
\text { and stress } \\
\text { Mindfulness }\end{array}$ \\
\hline Keng & Cohort & $\mathrm{N}=77$ & $\mathrm{~N}=57$ & Four weeks $\mathrm{x}$ three-hour & MAAS, PSS, DASS-21, & Pre and & Improvements in \\
\hline
\end{tabular}


HOLISTIK NURSING AND HEALTH SIENCE 1, (1), 2018 1-11

\begin{tabular}{|c|c|c|c|c|c|c|c|}
\hline (3) & control & $\begin{array}{l}\text { Fourth-year } \\
\text { medicine } \\
\text { (psych } \\
\text { rotation) } \\
\text { Self- } \\
\text { selected gp }\end{array}$ & $\begin{array}{l}\text { Fourth-year } \\
\text { medicine } \\
\text { (psych } \\
\text { rotation) } \\
\text { Self- } \\
\text { selected gp } \\
\text { Control- } \\
\text { nothing }\end{array}$ & $\begin{array}{l}\text { sessions of mindfulness - based } \\
\text { stress management (adapted } \\
\text { from MBCT and MBSR) - } \\
\text { "Mindful Gym." } \\
\text { Didactic teaching, mindful and } \\
\text { loving kindness meditation, } \\
\text { gratitude, mindful movement } \\
\text { and application of principles } \\
\text { 10-15 minutes daily MF } \\
\text { exercises.(guided by } \\
\text { instructions on DVD) 15-20 } \\
\text { per group }\end{array}$ & $\begin{array}{l}\text { GHQ-12, SHS, and } \\
\text { SWLS }\end{array}$ & $\begin{array}{l}\text { immediately } \\
\text { post }\end{array}$ & $\begin{array}{l}\text { depressive symptoms, } \\
\text { perceived stress, } \\
\text { anxiety, subjective } \\
\text { happiness, and } \\
\text { satisfaction with life } \\
\text { Looked at the effect of } \\
\text { trait mindfulness and } \\
\text { whether mediated } \\
\text { mindfulness. }\end{array}$ \\
\hline $\begin{array}{l}\text { Erogul et al. } \\
\text { (4) }\end{array}$ & RCT & $\mathrm{N}=29$ & $\mathrm{~N}=30$ & $\begin{array}{l}\text { MBSR involved } 75 \text { minutes, } \\
\text { once/week for eight weeks gp } \\
\text { instruction and } 20 \text { minutes } \\
\text { individual home med/day X } \\
\text { eight weeks. MBSR involved } \\
\text { teaching MF med, body scan } \\
\text { and breathing-based yoga and } \\
\text { cognitive curriculum } \\
\text { After week } 4 \text { shifted from } \\
\text { guided to self-med. }\end{array}$ & PSS, SCS, and RS & $\begin{array}{l}\text { Pre and } \\
\text { immediately } \\
\text { post- } \\
\text { intervention and } \\
\text { six months post- } \\
\text { intervention }\end{array}$ & $\begin{array}{l}\text { Perceived stress at } \\
\text { study end, not a six- } \\
\text { month post } \\
\text { intervention } \\
\text { self-compassion scores } \\
\text { at the end and six } \\
\text { months post RS scores } \\
\text { no change at end or } 6 \\
\text { months post }\end{array}$ \\
\hline $\begin{array}{l}\text { deVibe et al. } \\
\text { (5) }\end{array}$ & RCT & $\begin{array}{l}\mathrm{N}=144 \\
\text { Medical / } \\
\text { psychology }\end{array}$ & $\begin{array}{l}\mathrm{N}=144 \\
\text { Medical / } \\
\text { psychology }\end{array}$ & $\begin{array}{l}\text { MBSR Kabat Zinn } \\
\text { One and a half hours X seven } \\
\text { weeks, six hours session, } 30 \\
\text { minutes daily MF prac }\end{array}$ & $\begin{array}{l}\text { GHQ, MBI, PMSS, } \\
\text { SWB, FFMQ, Self-report } \\
\text { practice and \# classes } \\
\text { attended }\end{array}$ & $\begin{array}{l}\text { Pre-and post } \\
\text { intervention }\end{array}$ & $\begin{array}{l}\text { Moderate decrease } \\
\text { mental distress, small } \\
\text { in crease subjective } \\
\text { well-being and } \\
\text { mindfulness facet in } \\
\text { the intervention group }\end{array}$ \\
\hline
\end{tabular}


HOLISTIK NURSING AND HEALTH SIENCE 1, (1), 2018 1-11

\begin{tabular}{|c|c|c|c|c|c|c|c|}
\hline Kang et al. (6) & RCT & $\mathrm{N}=16$ & $\mathrm{~N}=16$ & $\begin{array}{l}\text { MBSR X eight weekly, one } \\
\text { and a half to two-hour sessions } \\
\text { MF med - body scan, breathing } \\
\text { and walking med followed by } \\
\text { self reflection }\end{array}$ & $\begin{array}{l}\text { BP, HR, self- } \\
\text { administered } \\
\text { questionnaire, PWISF, } \\
\text { STAI, and BDI }\end{array}$ & $\begin{array}{l}\text { Pre and one } \\
\text { week following } \\
\text { intervention }\end{array}$ & $\begin{array}{l}\text { Control and } \\
\text { intervention started } \\
\text { with one and a half } \\
\text { hour lecture stress and } \\
\text { coping, no diff } \\
\text { depression scores, } \\
\text { decrease stress and } \\
\text { anxiety scores in } \\
\text { intervention gp. }\end{array}$ \\
\hline $\begin{array}{l}\text { Ratanasiripong } \\
\text { et al }\end{array}$ & RCT & $\begin{array}{l}\mathrm{N}=29 \\
\text { mindfulness } \\
\text { meditation } \\
\text { Second year } \\
\text { nursing }\end{array}$ & $\begin{array}{l}\text { Second year } \\
\text { nursing }\end{array}$ & $\begin{array}{l}\text { Biofeedback gp two training } \\
\text { sessions on how to use the } \\
\text { equipment. } \\
\text { Mindfulness gp two training } \\
\text { sessions } \\
\text { On how to do Vipassana med. }\end{array}$ & PSS SAS from STAI & $\begin{array}{l}\text { Pre and } \\
\text { immediately } \\
\text { post }\end{array}$ & $\begin{array}{l}\text { Biofeedback- } \downarrow \\
\text { anxiety levels, } \\
\text { maintaining stress } \\
\text { levels. } \\
\text { Mindfulness- } \downarrow \\
\text { anxiety levels } \downarrow \text { and } \\
\text { perceived stress levels }\end{array}$ \\
\hline Young et al & $\begin{array}{l}\text { Non-RCT } \\
\text { cohort control }\end{array}$ & $\begin{array}{l}15 \text { third - } \\
\text { year nursing } \\
\text { students }\end{array}$ & $\begin{array}{l}15 \text { third- } \\
\text { year } \\
\text { nursing } \\
\text { students } \\
\text { Control- } \\
\text { nothing }\end{array}$ & $\begin{array}{l}\text { MBSR } 8 \text { week course yoga, } \\
\text { breathing, and body scan being } \\
\text { mindful }\end{array}$ & $\begin{array}{l}\text { F36 health survey, SCL - } \\
90 \text { and MMPI (Symptom } \\
\text { check list) }\end{array}$ & $\begin{array}{l}\text { Pre and post } \\
\text { intervention }\end{array}$ & $\begin{array}{l}\text { Small to medium effect } \\
\text { for health related, sense } \\
\text { of coherence and } \\
\text { physical symptoms } \\
\text { Psychological } \\
\text { symptoms greatest } \downarrow\end{array}$ \\
\hline
\end{tabular}


HOLISTIK NURSING AND HEALTH SIENCE 1, (1), 2018 1-11

\begin{tabular}{|c|c|c|c|c|c|c|c|}
\hline Astin & RCT & $\begin{array}{l}\mathrm{N}=14 \\
\text { Behavioral } \\
\text { medicine }\end{array}$ & $\begin{array}{l}\mathrm{N}=14 \\
\text { Behavioral } \\
\text { medicine } \\
\text { Wait list } \\
\text { control }\end{array}$ & $\begin{array}{l}\text { MBSR, Kabat Zinn } 8 \mathrm{wk} / 2 \mathrm{~h} \\
\text { Home }=45 / \mathrm{d} \\
\text { Med-body scan, sitting med, } \\
\text { hatha yoga, and didactic } \\
\text { presentations on stress No } \\
\text { eight-hour retreat }\end{array}$ & $\begin{array}{l}\text { Hopkins SC-90R (SLC- } \\
\text { 90_R) + additional items } \\
\text { scale5 sleeping and } \\
\text { eating GSI, SCI, } \\
\text { INSPIRIT, and daily } \\
\text { compliance diaries } \\
\text { Questioned whether } \\
\text { received something of } \\
\text { value and what that was. }\end{array}$ & $\begin{array}{l}\text { Pre post at eight } \\
\text { weeks } 6-9 \\
\text { months post } \\
\text { (but only } 5 \text { of } \\
12 \text { participants } \\
\text { and only GSI) }\end{array}$ & $\begin{array}{l}\downarrow \text { Overall psych } \\
\text { symptoms, } \uparrow \text { sense of } \\
\text { control and use of } \\
\text { accepting or yielding } \\
\text { mode of control, higher } \\
\text { scales on measures of } \\
\text { spiritual experiences } \\
\text { in intervention gp post } \\
+ \text { ve changes } \\
\text { maintained on GSI at } \\
\text { six to nine }\end{array}$ \\
\hline Yamada & Non RCT & $\mathrm{N}=37$ & $\mathrm{~N}=23$ & $\begin{array}{l}\text { Brief introductory material } \\
\text { provided at first session } 10 \mathrm{~min}- \\
\text { guided sitting MF meditation at } \\
\text { start of Psych class }+2 / w k+15 \\
\text { weeks led by instructor }\end{array}$ & $\begin{array}{l}\text { Psychological well- } \\
\text { being_FMI, MAAS, } \\
\text { SCS, RRQ, PSS, and } \\
\text { STAI } \\
\text { Sense of capacity for } \\
\text { learning_- evaluation of } \\
\text { mindful awareness } \\
\text { practices } \\
\text { Learning out comes- } \\
\text { total scores + class } \\
\text { assessments, for } \\
\text { example, peer } \\
\text { evaluations and exams }\end{array}$ & $\begin{array}{l}\text { Pre-and post } \\
\text { intervention }\end{array}$ & $\begin{array}{l}\uparrow \text { In mindful awareness } \\
\text { traits, } \downarrow \text { in rumination, } \downarrow \\
\text { state anxiety in } \\
\text { intervention gp, no diff } \\
\text { in academic } \\
\text { performance, but } 81 \% \\
\text { of students reported + } \\
\text { ve effects of MAPS on } \\
\text { learning }\end{array}$ \\
\hline
\end{tabular}




\section{Interventions \\ Yoga Therapy}

The purpose of this therapy is to reduce stress in individuals. Studies on the comparison of stress levels between men and women is still very limited. A study shows that yoga can reduce stress both in men and women (Sharma, 2012). This finding is supported by another study that yoga is associated with increased Gamma Amino Butyric Acid (GABA) associated with the relaxation process in the body (Streeter CC, 2007).

\section{MBSR therapy}

The MBSR program has been studied, and scientific evidence has shown that MBSR can have profound benefits through mind-body connections; the practice of mindfulness results in stress reduction (Center mindfulness 2014; Kabat-Zinn, 2003). There are several types of mindfulness therapy such as Mindfulness Based Stress Reduction (MBSR) and Mindfulness Meditation. MBSR is one type of therapy of mindfulness commonly used as an intervention of research. MBSR program is conducted as an 8 to the 10-week course, meeting 2-2.5 hours weekly coupled with home practice most days. An all-day intensive mindfulness session for 7-8 h in one day is held around the sixth week (Song \& Lindquist, 2015).

MBSR programs are based on teaching participants to react nonjudgmentally to stressful events by focusing on automatic and dynamic stimuli (breath; body; eating; walking), and participants cultivate these skills (Zeidan, Johnson, Diamond, David, \& Goolkasian, 2010). MBSR programs have been studied, and scientific evidence has been generated demonstrating that they can have a profound benefit via the mind-body connection; the practice of mindfulness results in an increase of awareness (Kabat-zinn, 2003).

\section{Meditation therapy}

Meditation is a mental exercise that can balance ones' physical, emotional, mental, and spiritual aspects (Iskandar, 2008). Meditation is the focusing of the mind toward the state of consciousness which brings the status of tranquility, clarity, and happiness that is the medium of the NSR (Sukmono, 2009). A study by Majid (2003) mentions that physical stress can be reduced by meditation.

All the aforementioned therapies in this systematic review are incorporated in mindfulness interventions. The differences in these three methods rely on the time duration and mode of administration. Intervention with yoga usually lasts for 15 minutes for 8 weeks, while MBSR lasts for 6-8 weeks with a duration of about 1-2 hours. Meanwhile, meditation is usually performed for 4-6 weeks with a duration of 1015 minutes.

\section{Effectiveness of mindfulness on decreasing stress level}

Of the 10 articles reviewed, it was found that Mindfulness can decrease stress in professional health students, with a very significant p-value. A study by Barbosa (2013) with a population of 1300, in which 12 were selected for interventions samples and 14 
were for the control group, reported that stress was a big problem for nursing students. In this study, it was also reported that mindfulness-based intervention conducted for 8 weeks with a duration of 35 minutes could decrease the stress level with a significant pvalue of 0.005 .

Yeoungsuk Song in 2015 also conducted a study with a population of 50 nurse students. Of this number, 44 students participated in the study and the other 6 students refused for participation. The selected students were divided into the treatment group $(n=21)$ and control group $(n=23)$. A mindfulness intervention was given for 8 weeks to the intervention group. The results indicated that mindfulness gave an influence on decreasing stress, anxiety and depression with p-value $=0.005$.

DeVibe MBSR Kabat Zinn One and a half hours X seven weeks, six hours session, 30 minutes daily MF prac.The selected student were divied student $\mathrm{N}=144 \mathrm{Medical} /$ psychology. Moderate decrease mental distress, small in crease subjective well-being and mindfulness facet in the intervention group. GHQ, MBI, PMSS, SWB, FFMQ, Selfreport practice and \# classes attended. Pre-and post intervention

Kang (2009) carried out a study on 41 nursing students. In this study, 21 students were assigned to the treatment group, and the other 20 were to the control group. The treatment in the form of mindfulness therapy was given for 8 weeks; each session lasted for 1-2 hours. The results reported significant reduction of stress $(F=6.145, p=0.020)$, anxiety $(\mathrm{F}=6.985, \mathrm{p}=0.013)$, and insignificant results were found in depression $(\mathrm{t}=$ 1.986, $\mathrm{p}=0.056$ ). A similar finding was also reported by Ratanasiripong (2015). Mindfulness gave significant effects on reducing stress in students $(p=0.005)$. In this study, 29 students were selected for the treatment group, and 31 were taken for the control group. The intervention was performed for 8 weeks; 2 meeting sessions each week Ratanasiripong (2015).

Furthermore, Yamada (2012) also conducted a study on the effects of mindfulness. The study recruited the samples of 60 participants (37 in the treatment group and 23 in the control group). Mindfulness intervention was given to the treatment group for 15 weeks. Two meeting session were carried out in each week. The results reported significant decreases in psychology students $(\mathrm{F}(1.55)=5.389, \mathrm{p}<.05)$ but not significant after treatment over 6 months.

Erogul et al. (2014) also reported that mindfulness with a combination of selfcompassion have significant effects in reducing stress $(0.58, \mathrm{p}=.23), 95 \%$ CI [0.23, 0.92]. This study was aimed at investigating stress in medical students. A total of 29 students in the control group and 30 in the intervention group were recruited. Mindfulness intervention was given once a week for 75 minutes in 4 weeks. Mindfulness gave significant effects on reducing the students' stress level (Erogul et al., 2014). Another interesting finding was also reported by Keng (2015). Mindfulness intervention in 4 weeks and 3 hours in each session significantly reduced stress in the students $(\mathrm{p}<0.05)($ Keng, 2015). 
Mindfulness was also evident to decrease stress in medical and psychology students (Vibe, Solhaug, \& Tyssen, 2015). Vibe, Solhaug, \& Tyssen (2015) investigated the effects of mindfulness in an intervention group $(n=144)$ of medical and psychology students. A control group of 144 students was also used. Mindfulness intervention was given to the intervention group for 7 weeks; each meeting lasted for 30 minutes. The results reported very significant of mindfulness (5.3 versus 3.6, t286 $=5.37, \mathrm{p}<0.001, \mathrm{~d}$ $=0.7$ ) (Vibe, Solhaug, \& Tyssen, 2015).

\section{DISCUSSION}

Mindfulness is such a therapy which is practiced by developing an awareness of oneself, with a sense of acceptance and not judging whatever happens to him (Kabat-Zinn, 1994). Mindfulness is a self-observation that distances the perception and response, allowing the mind to respond to the situation more effectively to the real reality. Hayes and Feldman (2004) mentioned that the state of mindfulness about oneself would clarify what he really feels to cure (fix) his mood with cognitive flexibility.

In dealing with stress in students, there are several therapy alternatives which can be used; one of which is mindfulness. It is evident that mindfulness can reduce the stress since this therapy can lead a person reach an alpha brain wave, i.e., a low frequency of brain wave. This alpha brain wave increases the secretion of norepinephrine, serotonin, and beta-endorphin levels, accompanied by a reduction in the level of blood production. The level of blood production is directly related to stress (Afandi et al., 2015, p. 76).

In studies conducted by Yamada et al. (2012), Yeoungsuk (2015), Astin (1997), Ratanasiripong (2015), Vibe, Solhaug, \& Tyssen (2015), Barbosa (2013), Kang (2009), Erogul et al. (2014), and Song (2015), it was reported that mindfulness could significantly decrease stress. Mindfulness is varied, especially in the matter of duration and length of time of administration. In average, mindfulness therapy was administered for more than 4 weeks. Yamada et al. (2012) also pointed out that after 6 months, mindfulness therapy should be re-administered to the students to decrease their stress.

\section{CONCLUSIONS AND IMPLICATIONS}

From this review, it can be concluded that mindfulness can reduce stress in the health professional students. The type of mindfulness administered to the health professional students, in average, is MBSR. This intervention is practiced through meditation which lasts for 5-35 minutes for 3-6 weeks. In this review, it was evident that MBSR could significantly reduce stress in students.

\section{REFERENCES}

Barbosa P, Raymond G, Zlotnick C, Wilk J, Iii RT, Iii JM. (2013). Mindfulness-Based Stress Reduction Training is Associated with Greater Empathy and Reduced Anxiety for Graduate Healthcare Students. Educ. Health, 26(1):9-14.

Song Y, Lindquist R. (2015). Effects of mindfulness-based stress reduction on depression, anxiety, stress, and mindfulness in Korean nursing students. Nurse Education Today, 35(1):86-90. Available online at http://dx.doi.org/10.1016/j.nedt.2014.06.010 
Keng S. Effects of a Brief Mindfulness- Based Intervention Program on Psychological Symptoms and Well-Being Among Medical Students in Malaysia: A Controlled Study. 2015;8(4):335-50.

Journal AI, Erogul M, Singer G, Mcintyre T, Stefanov DG, Singer G, et al. Abridged Mindfulness Intervention to Support Wellness in First-Year Medical Students Abridged Mindfulness Intervention to Support Wellness in First-Year Medical Students. 2014;1334(May 2017).

Vibe M De, Solhaug I, Tyssen R. Does Personality Moderate the Effects of Mindfulness Training for Medical and Psychology Students ? 2015;281-9.

Sik Y, Young S, Ryu E. Nurse Education Today The effectiveness of a stress coping program based on mindfulness meditation on the stress, anxiety, and depression experienced by nursing students in Korea. Nurse Educ Today [Internet]. Elsevier Ltd; 2009;29(5):538-43. Available from: http://dx.doi.org/10.1016/j.nedt.2008.12.003

Bluth, K., \& Blanton, P. (2015). The influence of self-compassion on emotional wellbeing among early and older adolescent males and females, Journal of Positive Psychology, 10(3), 219e230.http://dx.doi.org/10.1080/17439760.2014.936967

Afandi, Nur Aziz., et all. 2015. Efektifitas pelatihan Mindfulness terhadap penurunan stress korban kekerasan dalam pacaran (KDP). Diunduh pada tanggal 26 Maret 2017

RatanasiripongP, ParkJF, RatanasiripongN, KathalaeD. Stress and anxiety management in nursing students : biofeedback and mindfulness meditation. J NursEduc. 2015;54(9):520-524.

YoungLE, BruceA, TurnerL, LindenW. Evaluation of mindfulness -based stress reduction intervention. Can Nurse. 2001;97(6):23-26.

1Astin, J.A. Stress reduction through mindfulness meditation. Effects on psychological symptomatology, sense of control, and spiritual experiences. Psychother Psychosom. 1997;66(2):97-106.

Yamada K, VictorTL. The impact of mindful awareness practices on college student health, well-being, and capacity for learning: a pilot study. Psychol LearnTeach. 2012;11(2):139-145. 